Ks. Dariusz Piasecki ${ }^{1}$

\title{
Mysterium mortis w ujęciu Anastazego Synaity
}

\section{Wstęp}

W niniejszym artykule zostanie zaprezentowana myśl Anastazego Synaity dotycząca chrześcijańskiego spojrzenia na śmierć ${ }^{2}$. Mnich z Synaju traktuje tematykę umierania w szerokim aspekcie, ujmując nie tylko sam moment ludzkiego odejścia wraz z towarzyszącymi mu zjawiskami, ale również zachowanie umierającego, prezentuje też religijną perspektywę odejścia i tego, co jest po niej.

Literatura światowa w niewielkim stopniu zajmowała się dziełami autorstwa Anastazego ${ }^{3}$. Polska bibliografia patrystyczna prezentuje nieliczne i wybrane fragmenty kilku mów, które zostały przełożone na język

1 Ks. dr Dariusz Piasecki, filolog klasyczny, absolwent KUL; e-mail: sabulum@interia.pl; ORCID: 0000-0001-5702-735X.

2 Anastasius Sinaita, Sermo in defuntos perutilis, PG 89, 1192-1201.

3 W ostatnim dwudziestoleciu pojawiają się opracowania twórczości Anastazego Synaity. Należą do nich m.in. K.-H. Uthemann, Anastaios Sinaites. Byzantinisches Christentum in den ersten Jahrzehnten unter arabischer Herrschaft, t. 1-2, Berlin - Boston 2015; K.-H. Uthemann, Studien zu Anastasios Sinaites. Mit einem Anhang zu Anastasios I. von Antiochien, Berlin - Boston 2017; Anastasii Sinaitae Quaestiones et responsiones, ed. M. Richard - J.A. Munitiz, Turnhout - Leuven 2006. Daje się również zauważyć rosnące zainteresowanie twórczością Anastazego Synaity i poruszaną przez niego tematyką w konferencjach naukowych: Erotapokriseis: Early Christian Question-and-Answer Literature in Context: Proceedings of the Utrecht Colloquium, 13-14 October 2003, ed. A. Volgers - C. Zamagni, Leuven - Paris - Dudley 2004. 
polski ${ }^{4}$. Anastazy Synaita wydaje się być niemal nieobecny w polskiej literaturze naukowej. Tym bardziej warto podjąć się analizy naukowej jego dzieł i przybliżyć polskiej nauce walor teologicznej i filologicznej myśli mnicha z synajskiego klasztoru św. Katarzyny.

Celem artykułu jest odpowiedzi na pytanie, w jaki sposób Anastazy Synaita rozumie śmierć chrześcijanina. Odpowiedź zostanie sformułowana w oparciu o wygłoszoną przez opata z klasztoru św. Katarzyny mowę na pogrzebie jednego z zakonników, do którego wspólnoty miał należeć jej autor ${ }^{6}$. Nakreśla on chrześcijańską wizję śmierci oraz rzeczywistości post mortem. Stanowi to pewnego rodzaju konsolację, jak i formę chrześcijańskiego przygotowania do umierania. Na treść homilii składają się zagadnienia ludzkiej przygodności związanej z nieuchronnością odejścia, agonii umierającego stanowiącą przedmiot refleksji dla pozostających oraz ostatnie jego słowa będące testamentem. Na treść składa się również moment odejścia i autorska wizja post mortem, które, wpływając na ludzką wyobraźnię, skłaniają do nawrócenia. Motywem, który spaja całość homilii, jest konieczność duchowego przygotowania do śmierci oraz towarzyszące temu poczucie smutku i opuszczenia.

Artykuł składa się z pięciu punktów poprzedzonych krótką notką o autorze. W pierwszym punkcie zostanie zaprezentowana niebiańska wizja szczęścia przygotowana dla tych, którzy odeszli. W drugim z kolei los żywych pozostających w smutku i żałobie po odejściu zmarłego. Trzeci punkt poświęcony jest fenomenologii umierania. Czwarty prezentuje ostatnie słowa umierającego zawarte w testamencie. Piąty punkt koncentruje się na rzeczywistości post mortem. W zakończeniu prezentowane są wnioski.

\footnotetext{
4 W. Stawiszyński, Bilbliografia patrystyczna 1901-2016, Kraków 2013, s. 91-92. Anastaius Sinaita, Sermo in defunctos perutilis, PG 89, 1192-1201.

6 Hiéromoine Nicolas (Molinier), Anastase le Sinaïte, Trois Homélies, Paris 2013, s. 89.
} 


\section{2. Życie i twórczość Anastazego Synaity}

Niewiele wiadomo na temat życia Anastazego Synaity. Wynika to zapewne $\mathrm{z}$ faktu utożsamiania go z patriarchą Anastazym I żyjącym niewiele wcześniej, w VI wieku, który również był pisarzem. Dla odróżnienia obu późniejsza hagiografia nadaje mu przydomek opata klasztoru św. Katarzyny na Synaju. Informacji dostarczają autobiograficzne wzmianki zawarte w jego dziełach. Urodził sie prawdopodobnie w Aleksandrii lub na Cyprze, w mieście Amathont ${ }^{7}$ w pierwszej połowie VII wieku, umarł w pierwszych latach VIII wieku ${ }^{8}$.

Po opuszczeniu ojczyzny wstąpił do wspólnoty monastycznej na Synaju prawdopodobnie w 660 roku ${ }^{9}$, gdzie, będąc mnichem, zajmował sie, administrowaniem szpitala ${ }^{10}$, dlatego uważa sie。 ze był lekarzem, na co wskazują liczne terminy medyczne obecne w jego pismach ${ }^{11}$. Nie jest też do końca pewne, jak długo Anastazy pozostawał członkiem wspomnianej wspólnoty, ponieważ wspomina w swoich pismach o wielu podróżach mających na celu utwierdzić w wierze błądzące wspólnoty chrześcijańskie. Umarł w pierwszych latach VIII wieku.

Anastazy Synaita jest autorem między innymi apologii chalcedońskiego wyznania wiary zatytułowanego Viae dux $x^{12}$, Quaestiones et responsiones $^{13}$, dzieła o charakterze katechizmu poruszającego kwestie moralne, ascetyczne i dyscyplinujące. Dzieło jest zbiorem odpowiedzi, jakie Anastazy udzielał chrześcijanom swojego czasu na nurtujące ich py-

(Molinier) Hiéromoine, Anastase Le Sinaïte, Trois Homélies, s. 11.
(Molinier) Hiéromoine, Anastase Le Sinaïte, Trois Homélies, s. 12.
(Molinier) Hiéromoine, Anastase Le Sinaïte, Trois Homélies, s. 11.
(Molinier) Hiéromoine, Anastase Le Sinaïte, Trois Homélies, s. 12.
M.-H. Congourdeau, Médecine et théologie chez Anastase le Sinaïte, médecin, moine et didascale, w: Les Pères de l'Église face à la science médicale de leur temps, red. V. Boudon-Millot - B. Pouderon, Paris 2005.

12 Anastasii Sinaitae Viae Dux, ed. K.-H. Uthemann, Turnhout - Leuven 2006.

13 Anastasii Sinaitae Quaestiones et responsiones, ed. M. Richard - J.A. Munitiz, Turnhout - Leuven 2006. 
tania. Ponadto jest autorem trzech homilii na temat stworzenia człowieka na Boże podobieństwo ${ }^{14}$.

\section{O tych, którzy odeszli}

Śmierć jednego z zakonników staje się okolicznością wygłoszenia przez Anastazego mowy pożegnalnej i zaprezentowania myśli dotyczącej chrześcijańskiej rzeczywistości post mortem. Autor homilii konstruuje swoją wypowiedź, posługując się metodą paralelnie zestawionych przeciwieństw, w oparciu o teksty biblijne i literackie porównania. Refleksję nad śmiercią rozpoczyna od inwokacji skierowanej do Chrystusa ${ }^{15}$, który gromadzi wokół siebie zarówno żywych, jak i zmarłych: $\Sigma v v \varepsilon \kappa \alpha ́ \lambda \varepsilon \sigma \alpha v$

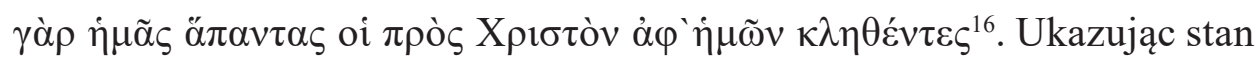
ludzi po śmierci, autor ujmuje go w opozycji do sytuacji, w jakiej znajdują się ci, którzy pozostają przy życiu. Śmierć kończy życie ziemskie człowieka, w ujęciu chrześcijańskim natomiast rozpoczyna nową jakość życia post mortem. Żywi trwają w tym, co zniszczalne, umarli podążają tam, gdzie nic się już nie niszczy. Jedni nadal trwają w kruchości swojego życia, drudzy dołączają do niebiańskiej szczęśliwości. Udziałem żywych są daremne starania, podczas gdy zmarli odchodzą do krainy spokoju ${ }^{17}$.

Anastazy, odwołując się wielokrotnie do ewangelicznych pojęć, dość często stosuje biblijną metaforykę dla określenia obu rzeczywistości, ziemskiej i niebieskiej. W tym ujęciu kruchość i przemijalność życia ${ }^{18}$ umieszcza w nietrwałym i tymczasowym ,namiocie”, o którym wspomina św. Paweł Aposto1' ${ }^{19}$, a które w pełni realizuje się dopiero

14 Anastasii Sinaitae Sermones duo in constitudinem hominis secundum imaginem Dei, necnon opuscula adversus monotheletas, ed. K.-H. Uthemann, Turnhout - Leuven 1985.

15 Anastasius Sinaita, Sermo in defunctos perutilis, PG 89, 1192.

16 Anastasius Sinaita, Sermo in defunctos perutilis, PG 89, 1192.

17 Anastasius Sinaita, Sermo in defunctos perutilis, PG 89, 1192-1193.

18 Anastasius Sinaita, Sermo in defunctos perutilis, PG 89, 1193.

19 Kor 5,1 . 


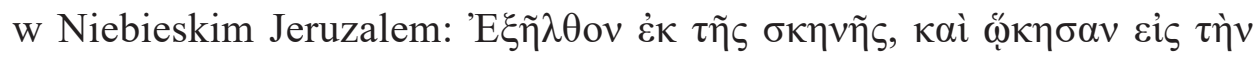

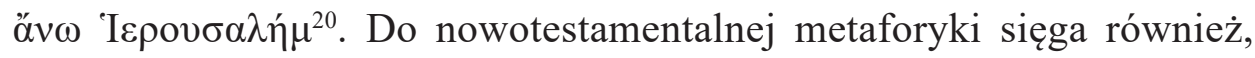
kiedy mówi o Ojczyźnie w niebie, do której człowiek, na wzór przodków ${ }^{21}$, zdąża za życia, aby posiąść ją po śmierci, stając się pełnoprawnym obywatelem Nieba ${ }^{22}$. Ono staje się przestrzenią wolną od wszelkiego zepsucia $^{23}$. Do niego, wstępując, zmarli pozostawiają za sobą to, co znisz-

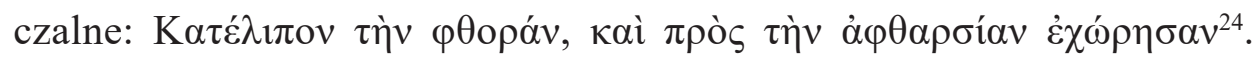
Wstąpiwszy do rzeczywistości pozaziemskiej, zmarli - na wzór ewangelicznych roztropnych panien ${ }^{25}$ - zapalają swoje lampy, którymi rozświetlają serca, aby dalej podążać w kierunku nieprzeniknionej światło-

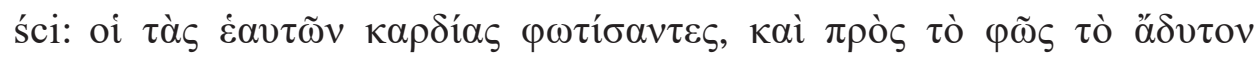

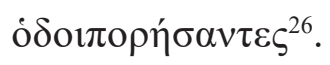

Omawiając powyższe zagadnienia, autor odwołuje się do obrazów zapożyczonych z praw natury. Według niego los zmarłych staje się lepszy od nadal żyjących, ponieważ śmierć uwalnia ich od burz i nawałnic doczesnego świata, dzięki czemu dobijają do portu niezmąconego spokoju: $\alpha \varphi \tilde{\eta} \kappa \alpha v$

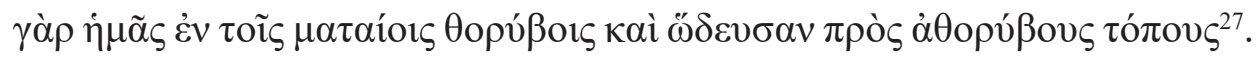
Odwołując się do morza i nawałnic, autor mowy sugeruje, że człowiek jest łódką na wielkim oceanie świata. Miotany falami niebezpieczeństw dopiero w porcie docelowym, jakim jest śmierć, znajduje ocalenie. Metaforyka okrętu podnoszona przez wielu pisarzy chrześcijańskich odnosi się do Kościoła. W ujęciu Anastazego każdy chrześcijanin jest okrętem płynącym do portu zbawienia. Autor w homilii podkreśla przygodność bytu ludzkiego, a ziemskie zamieszkania, bogactwo dają poczucie tylko iluzorycznego bezpieczeństwa. Kolejnym obrazem ukazującym uwolnienie człowieka od

\footnotetext{
20 Anastasius Sinaita, Sermo in defunctos perutilis, PG 89, 1193.

21 Hbr 11,13 .

22 Flp 3,20.

23 Mt 6,19.

24 Anastasius Sinaita, Sermo in defunctos perutilis, PG 89, 1193.

25 Mt 25,1-13.

26 Anastasius Sinaita, Sermo in defunctos perutilis, PG 89, 1192.

27 Anastasius Sinaita, Sermo in defunctos perutilis, PG 89, 1193.
} 
trudów życia jest przyrównanie odejścia człowieka do samotnej i słodko ćwierkającej jaskółki. W chwili śmierci umierający, podobnie jak ptak,

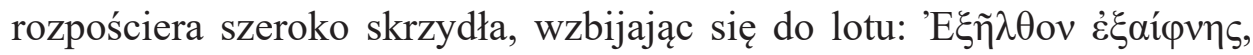

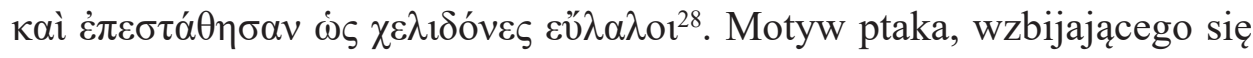
do nieba, Anastazy czerpie ze źródeł biblijnych ${ }^{29}$. Jest on symbolem nieskazitelności, czystości i wolności ${ }^{30}$.

Ważnym elementem tej części mowy Anastazego jest motyw niebieskiej liturgii. Tematyka ta pojawia się, kiedy autor porusza kwestię powinności, jakie mają do spełnienia zmarli. Pierwszym zadaniem zmarłych jest pobudzenie żywych, aby dopełnili Bożą chwałę w imieniu tych, któ-

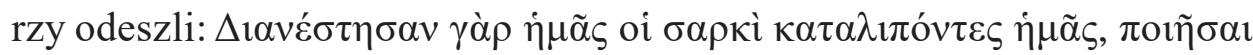
$\alpha$ ủ

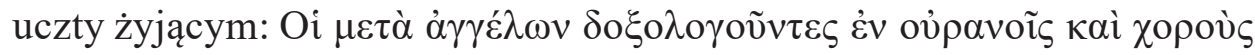

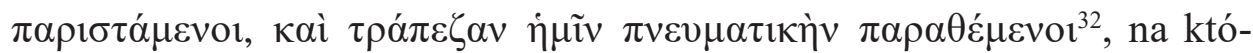
rej zmarli ofiarowują żywym wino prawdziwej skruchy ${ }^{33}$. Dzięki owej duchowej wymianie zawiązuje się swoista więź pomiędzy tymi, którzy celebrują już liturgię niebieską ${ }^{34}$, a tymi, którzy poprzez duchowo-ascetyczne formy ziemskiego przygotowania oczekują wypełnienia się czasu. Więź ta polega na zawiązywaniu się swoistego chóru złożonego z pielgrzymujących na ziemi, a radującymi się w niebie.

\section{Memento mori}

Po zaprezentowaniu chrześcijańskiej wizji losu człowieka po śmierci Anastazy kieruje swoją uwagę w kierunku pozostających przy życiu ża-

\footnotetext{
28 Anastasius Sinaita, Sermo in defunctos perutilis, PG 89, 1193.

29 Ps 55,7; Iz 38, 14.

30 Mt 10,16.

31 Anastasius Sinaita, Sermo in defunctos perutilis, PG 89, 1192.

32 Anastasius Sinaita, Sermo in defunctos perutilis, PG 89, 1192.

33 Anastasius Sinaita, Sermo in defunctos perutilis, PG 89, 1192.

34 Anastasius Sinaita, Sermo in defunctos perutilis, PG 89, 1193.
} 
łobników. Czyni to po to, aby uświadomić im nie tylko poczucie straty po zmarłym, ale również, aby zachęcić do czujności oraz do niesienia pomocy tym, którzy odeszli. Konstruując tę część mowy, autor nawiązuje między innymi do motywów porzucenia, owczarni, gniazda, a nawet jarzma. W celu zobrazowania wspomnianych wątków autor sięga do porównań zaczerpniętych z życia zwierząt. Przyrównuje żałobników do zagubio-

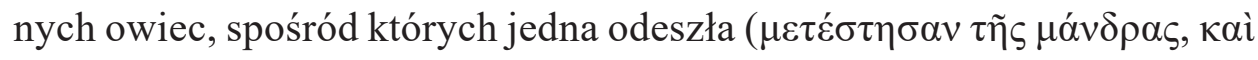

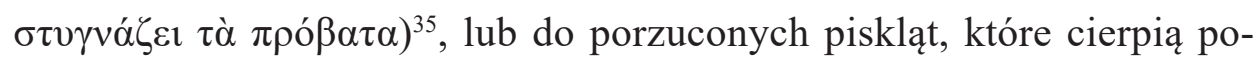

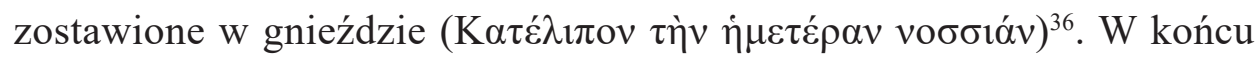
przyrównuje żałobników do płaczących wołów, które ryczą boleśnie na

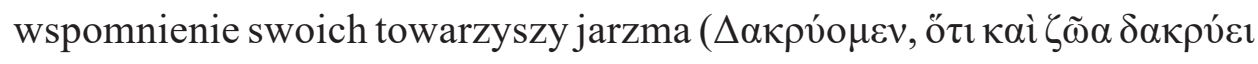

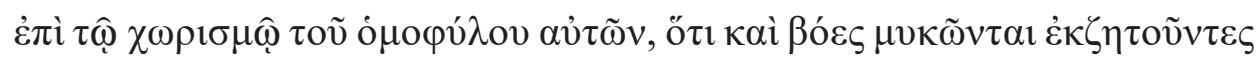

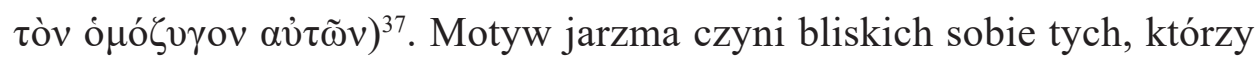
dzielą podobny los. Podobnie jak zdolne do cierpienia są zwierzęta, tym bardziej człowiek, kiedy nagle i niespodziewanie śmierć wyrywa z jego otoczenia bliską mu osobę. Cierpienie, smutek, żal, rozpacz i łzy potęgują poczucie straty i stają się udziałem „ograbionych” z obecności zmarłej

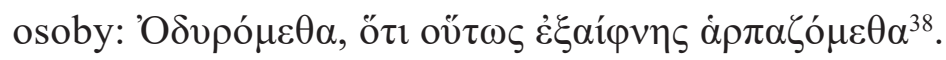

Emocje związane z poczuciem straty po zmarłym mają za zadanie według autora homilii uświadomić żałobnikom, że śmierć jest nieprzewidywalna i nieuchronna. Anastazy w mowie bezpośredniej kieruje się do każdego słuchacza, wskazując na możliwe okoliczności rozłąki, jak: „niewinna gorączka” czy ,jakieś małe cierpienie”, które zatrzymują nagle ludzkie życie, a człowiek jak skazaniec poprowadzony zostanie na sąd ${ }^{39}$. Odchodzi sam i samotny, pokorny i nagi, bez pomocy i wsparcia, bez przygotowania i zabezpieczenia, dlatego По $\lambda \lambda \tilde{\omega} \nu$ бoı

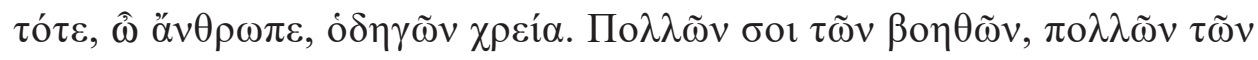

\footnotetext{
35 Anastasius Sinaita, Sermo in defunctos perutilis, PG 89, 1193.

36 Anastasius Sinaita, Sermo in defunctos perutilis, PG 89, 1193.

37 Anastasius Sinaita, Sermo in defunctos perutilis, PG 89, 1193.

38 Anastasius Sinaita, Sermo in defunctos perutilis, PG 89, 1193.

39 Anastasius Sinaita, Sermo in defunctos perutilis, PG 89, 1196.
} 


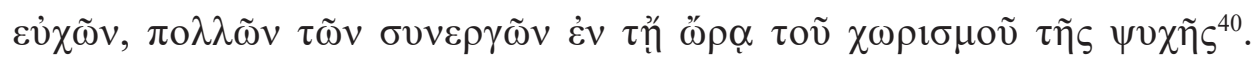
Anastazy wskazuje tu na niezbędną i konieczną rolę przewodnika na drodze prowadzącej na sąd. Autor jednak nie precyzuje roli, jaką miałby do spełnienia ów przewodnik, choć w kolejnych słowach odnosi się do udzielenia zmarłemu modlitewnej pomocy. Można by zatem przyjąć, że przewodnik towarzyszy w drodze zmarłemu i wspiera swoimi modlitwami. Kiedy człowiek udaje się w rzeczywistość post mortem, odczuwa według Anastazego ogromną trwogę, wielki strach, ponieważ wchodzi w tajemnicę, która potęguje jego zakłopotanie, a drogi powrotnej stamtąd już nie ma ${ }^{41}$. Wyjątkowość, a zarazem tragizm tego przejścia autor podkreśla poprzez zastosowanie niepowtarzalnych okoliczności, jak: ,jedyna godzina i nie ma drugiej takiej”, ,jedyna taka droga i nie ma innej”, ,,jedyny most i nie ma drogi powrotnej”, ${ }^{42}$, sam zaś proces odłączenia duszy od ciała przyrównuje do „bolesnego przejścia”, którego wszyscy muszą doświadczyć, lub też do „gorzkiego kielicha”, który wypić musi każdy ${ }^{43}$. Na podstawie powyższego można przyjąć, że Anastazy rozumie śmierć w antropologicznym aspekcie tego wydarzenia jako odłączenie duszy od ciała. Pobudzając natomiast wyobraźnię swoich słuchaczy z powodu nadchodzącej i nieoczekiwanej śmierci,

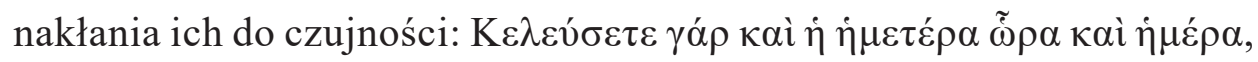

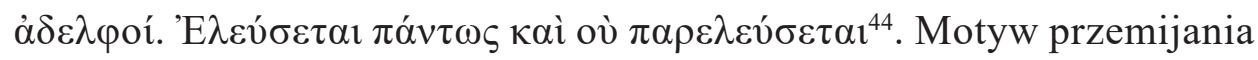
oraz bezlitośnie upływającego czasu, złudnego jego posiadania skierowany byłby do tych, którzy jakiekolwiek formy pokuty odsuwaliby na bliżej nieokreślony termin, żyjąc w lenistwie, na sposób zmysłowy i tracąc lekkomyślnie $\operatorname{czas}^{45}$.

\footnotetext{
40 Anastasius Sinaita, Sermo in defunctos perutilis, PG 89, 1196.

41 Anastasius Sinaita, Sermo in defunctos perutilis, PG 89, 1196.

42 Anastasius Sinaita, Sermo in defunctos perutilis, PG 89, 1196.

43 Anastasius Sinaita, Sermo in defunctos perutilis, PG 89, 1196.

44 Anastasius Sinaita, Sermo in defunctos perutilis, PG 89, 1196.

45 Anastasius Sinaita, Sermo in defunctos perutilis, PG 89, 1196.
} 


\section{Fenomen umierania}

Niezwykle subiektywną wypowiedzią Anastazego jest refleksja na temat samego zjawiska umierania. W tej części mowy autor odwołuje się do motywu bezsilności wobec przemijania oraz do motywu konsolacji pozostających po zmarłym. Moment śmierci i zespół zachowań, jakie towarzyszą zarówno umierającemu, jak i żałobnikom Anastazy

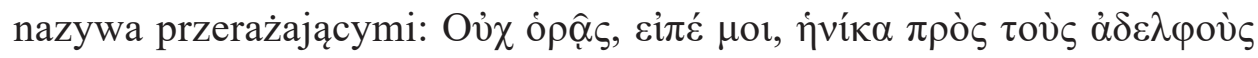

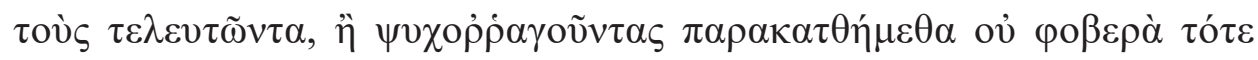
ó $\tilde{\mu} \mu \varepsilon v ;{ }^{46}$. Pobudzając wyobraźnię słuchacza, zwraca się do niego bezpośrednio słowami Oỏ ó $\rho \hat{\alpha} \varsigma^{47}$, aby następnie uwagę żałobników skupić na zewnętrznych objawach umierającego. Należą do nich gest wzniesionej dłoni, powolne poruszanie się, wzdychanie, pojawienie się zimnego i nieprzyjemnego potu. Wystąpienie na ciele ,zimnego potu” mówca przyrównuje do trudu i znoju żniwiarzy pracujących na polu: $\omega \varsigma$ oi $\dot{\varepsilon} v$ $\dot{\alpha} \gamma \rho \hat{\varphi} \theta \theta \varepsilon \rho \sigma \tau \alpha i^{48}$. W porównaniu tym można dostrzec pewną analogię do ewangelicznych żeńców-aniołów ${ }^{49}$, których zadaniem będzie oddzielenie grzeszników od sprawiedliwych. Do kolejnych oznak charakterystycznych zjawisku umierania należą występowanie zimnych dreszczy, zgrzytanie zębami, plączący się język oraz niemoc ciała przykuwająca chorych do łoża śmierci. Tym fizycznym objawom towarzyszą również zjawiska, których wcześniej odchodzący nie doświadczali. Anastazy wymienia między innymi dostrzeganie rzeczy, których wcześniej chory nie widział, głosy, których wcześniej nie słyszał, w końcu doświadczenie cierpienia, którego wcześniej nie odczuwał. Wszystkie te objawy sprawiają, że umierający szuka jakiegoś wybawiciela i tego, kto mógłby go w takiej sytuacji pocieszyćs ${ }^{50}$. Taki widok odchodzącej osoby nie jest obojętny obecnym

\footnotetext{
46 Anastasius Sinaita, Sermo in defunctos perutilis, PG 89, 1196.

47 Anastasius Sinaita, Sermo in defunctos perutilis, PG 89, 1196.

48 Anastasius Sinaita, Sermo in defunctos perutilis, PG 89, 1196.

49 Mt 13,24-30.36-43.47-53.

50 Anastasius Sinaita, Sermo in defunctos perutilis, PG 89, 1196.
} 
wokół niej i wywołuje u nich takie reakcje, jak: drżenie, płacz, wylewanie morza łez, gesty chwytania umierającego za dłonie, ocieranie z czoła, twarzy i oczu potu, nawilżanie zeschniętego języka, potrząsanie głową, żal, nachylanie się do ust umierającego, aby zrozumieć szeptem wypowiadane słowa, czy też zadawanie pełnych troski pytań o samopoczucie chorego czy jego potrzeby. Współczujący starają się pocieszać umierającego, podnosić na duchu, wlewać nadzieję i otuchę: Mì ó $\Theta \varepsilon o ́ \varsigma^{51}$. W obliczu nadchodzącej śmierci człowiek przewartościowuje

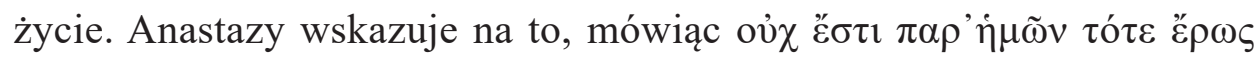

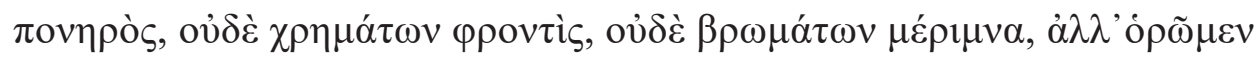

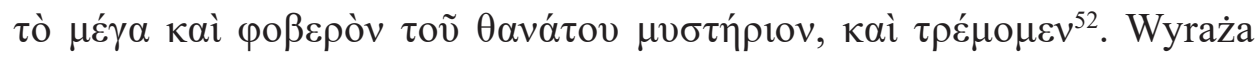
jednocześnie gorzką biblijną prawdę, że człowiek z prochu powstał i w proch się obróci ${ }^{53}$.

\section{Testament}

W tok pogrzebowej mowy Anastazy wkomponowuje wypowiedź osoby umierającej. Ma ona charakter mowy niezależnej, jest ostatnim przesłaniem umierającego do żywych, formą testamentu i obejmuje pozdrowienia zgromadzonych wokół, prośby o modlitwę i ostrzeżenia przed lekkomyślnym życiem. W kompozycji tej części mowy autor nawiązuje do antycznego motywu zejścia do krainy umarłych. Umierający kilkakrotnie żegna zgromadzonych, skierowując do nich gorącą prośbę o modlitwę, świadom szybkiego odejścia i wędrówki do krainy zmarłych. Nazywa ją ,krainą obcą, w której nie ma nikogo, kogo by znał; strasznym światem, z którego nikt nie wraca, krainą ciemności, z którego nikt się nie wydostał" ${ }^{54}$. Po raz kolejny Anastazy sięga do motywu porzucenia,

\footnotetext{
51 Anastasius Sinaita, Sermo in defunctos perutilis, PG 89, 1197.

52 Anastasius Sinaita, Sermo in defunctos perutilis, PG 89, 1197.

$53 \mathrm{Rdz} 3,19$.

54 Anastasius Sinaita, Sermo in defunctos perutilis, PG 89, 1197.
} 
zerwania więzi. Zejście do krainy umarłych każe zapomnieć o rodzinnych czy przyjacielskich koligacjach. Autor wkłada w usta umierającego

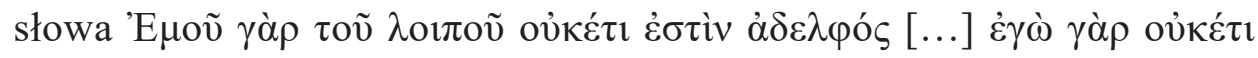

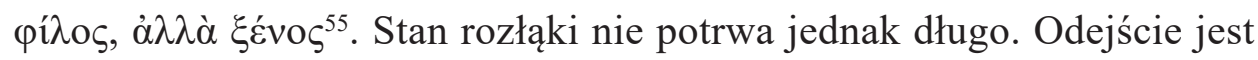

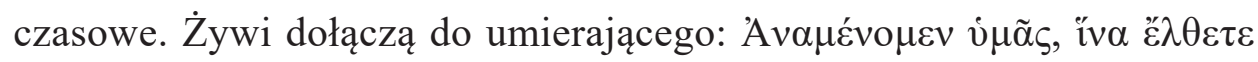
$\pi \rho \grave{\varsigma} \dot{v} \mu \tilde{\alpha} \varsigma^{56}$. W kolejnych wersetach autor homilii porusza zagadnienie zmarnowanego czasu. Motyw ten łączy z kwestią nagrody i kary, gdzie kara stanowi naturalną konsekwencję lekceważenia czasu i braku przygotowania na śmierć.

\section{Post Mortem}

W ostatniej część pogrzebowej mowy Anastazy porusza kwestię pośmiertnego losu zmarłego, na którą składa się motyw sądu ostatecznego oraz bardziej rozbudowane wnioski autora o charakterze dydaktycznym. Temat sądu autor poszerza o dodatkowe wątki: antropologiczny, angelologiczny oraz wątek walki o ludzką duszę. Anastazy podkreśla, że śmierć staje się momentem, kiedy człowiek definitywnie odchodzi: „Oto poszedł sobie, dobił do swego kresu, wszedł do odpoczynku"57. Słowa Synaity wskazują na cezurę oddzielającą agonalną rzeczywistość umierającego od autentycznego wejścia w mysterium mortis. W tym momencie zmienia się ludzka perspektywa. Ten, który za życia wydawał się być wielki, niezwyciężony oraz władcą, teraz leży pokonany, bardziej łagodny od baran-

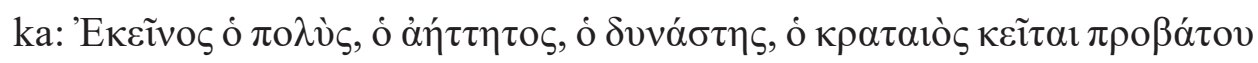

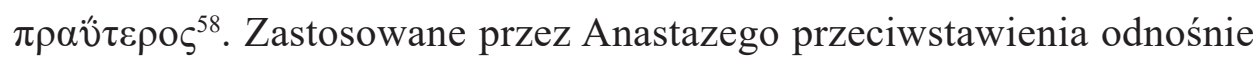
do zmarłego, jak: widoczny - jakby niewidoczny, potężny - pokonany, władca - baranek, pokazują nicość bytu ludzkiego wobec ostatecznego

\footnotetext{
55 Anastasius Sinaita, Sermo in defunctos perutilis, PG 89, 1197.

56 Anastasius Sinaita, Sermo in defunctos perutilis, PG 89, 1197.

57 Anastasius Sinaita, Sermo in defunctos perutilis, PG 89, 1200.

58 Anastasius Sinaita, Sermo in defunctos perutilis, PG 89, 1200.
} 
sądu, na który zmarły jest prowadzony. Motyw sądu Synaita prezentuje w sposób pejoratywny a zarazem przerażający jako spotkanie z surowymi oskarżycielami, poborcami, sędziami, dzierżawcami podatków, którzy skrupulatnie przepytują, badają, oskarżają, sporządzają listę ludzkich przewinień, popełnionych zarówno w młodości, jak i starości, z własnej woli czy nieświadomie, słowem, czynem i myślą ${ }^{59}$. Kaznodzieja przyrównuje oskarżycieli do wrogów ludzkiej duszy, których zadaniem jest

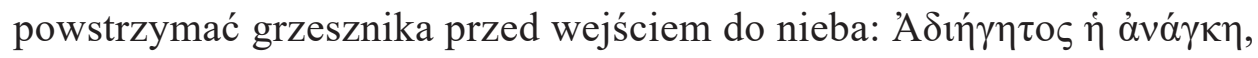

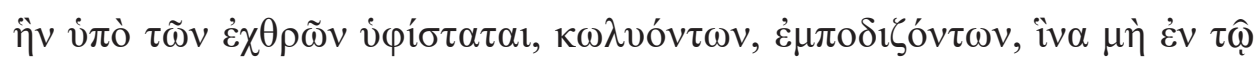

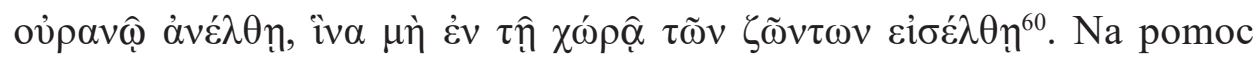
człowiekowi w tej walce przychodzą aniołowie. Ich zadaniem jest zabrać ludzką duszę sprzed trybunału surowych oskarżycieli: 'A $\lambda \lambda$ 'oi $\mu$ غ̀े $\alpha$ ó $\gamma 10$

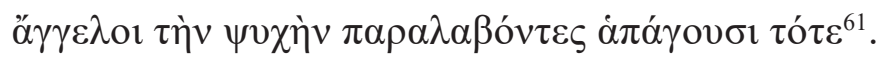

Wizja pośmiertnej rzeczywistości oraz nielitościwych sędziów, wobec których zmarły zdaje egzamin z całego życia, staje się dla Anastazego punktem wyjścia do sformułowania ostatecznych wniosków z wygłoszonej homilii. Mają one charakter dydaktyczny, są ostrzeżeniem, a jednocześnie zachętą, zawierają przestrogi, ale i wskazówki prowadzące do dobrego życia. Można je zredukować do dwóch terminów: czujność i nawrócenie. Prowadzą do tego praca, gotowość i zdolność przewidywania. Realizując powyższe wskazówki, autor proponuje porzucenie źle wykorzystywanej wolności, bierności w działaniu oraz zwodniczych nadziei ${ }^{62}$. Sięgając do obrazu ze świata zwierząt, Synaita, przestrzegając przed brakiem czujności, porównuje człowieka od wróbla, który nagle zostaje schwytany przez jastrzębia, lub do nieostrożnego

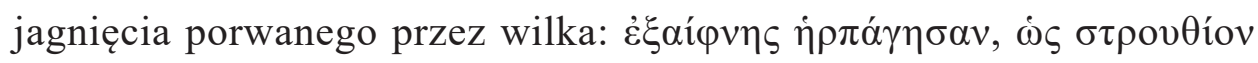

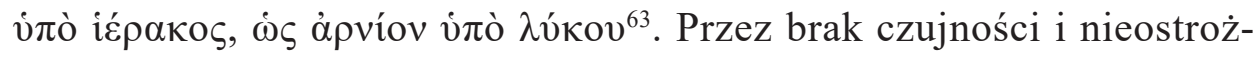

\footnotetext{
59 Anastasius Sinaita, Sermo in defunctos perutilis, PG 89, 1200.

60 Anastasius Sinaita, Sermo in defunctos perutilis, PG 89, 1200.

61 Anastasius Sinaita, Sermo in defunctos perutilis, PG 89, 1200.

62 Anastasius Sinaita, Sermo in defunctos perutilis, PG 89, 1201.

63 Anastasius Sinaita, Sermo in defunctos perutilis, PG 89, 1201.
} 
ność wielu odeszło nieprzygotowanych. Autor wskazuje na przyczynę, z powodu której człowiek nie otrzymuje od Boga przebaczenia. Polega ona na pełnej świadomości popełnianych czynów pomimo znajomości woli Boga ${ }^{64}$. Wzywa zatem, aby nie być tylko biernymi słuchaczami,

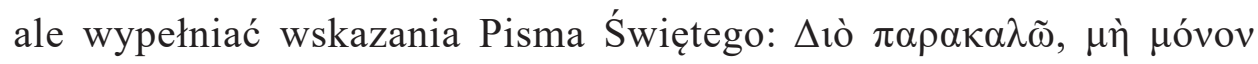

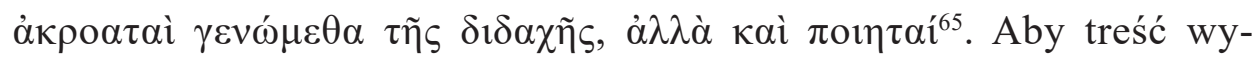
głoszonej homilii nie stała się oskarżeniem z powodu bierności, autor proponuje konkretne rozwiązania: na życie ponad miarę - hojność i jałmużnę, na gniew i żal - przebaczenie i zapomnienie ${ }^{66}$. Śmierć staje się nauczycielem życia dopiero wówczas, kiedy żywi wyciągają z niej wnioski: pierwszym jest karmienie się Słowem Bożym, które Synaita nazywa „ożywiającym pokarmem”67, drugim natomiast - mądrość płynąca z doświadczenia życia i świadectwa, jakie pozostawili po sobie zmarli, które autor określa „winem nauki”, jakie zmarli zmieszali dla żywych ${ }^{68}$. Motyw „ożywiającego pokarmu” i ,wina nauki” wskazuje na eucharystyczny pokarm, dzięki któremu człowiek nawiązuje komunię z Bogiem. Podobnie w tym przypadku Anastazy wskazuje na potrzebę posilania się zarówno jednym, jak i drugim, aby uniknąć i przezwyciężyć zgubne przyzwyczajenia i w ten sposób skierować umysł i duszę ku Bogu. Jak początek homilii rozpoczyna inwokacja autora skierowana do Chrystusa, tak jej koniec wieńczy doksologia ku czci Ojca, Syna i Ducha Świętego, która jak klamrą spaja całą mowę pogrzebową Anastazego Synaity ${ }^{69}$.

\footnotetext{
64 Anastasius Sinaita, Sermo in defunctos perutilis, PG 89, 1201.

65 Anastasius Sinaita, Sermo in defunctos perutilis, PG 89, 1201.

66 Anastasius Sinaita, Sermo in defunctos perutilis, PG 89, 1201.

67 Anastasius Sinaita, Sermo in defunctos perutilis, PG 89, 1201.

68 Anastasius Sinaita, Sermo in defunctos perutilis, PG 89, 1201.

69 Anastasius Sinaita, Sermo in defunctos perutilis, PG 89, 1201.
} 


\title{
8. Wnioski
}

Mowa pogrzebowa Anastazego Synaity została wygłoszona z okazji śmierci jednego ze współbraci konwentu, w którym autor przebywał. Treść przemowy staje się okazją do zaprezentowania myśli opata klasztoru na temat śmierci w kontekście wiary chrześcijańskiej. Na podstawie mowy pogrzebowej Anastazego można wysunąć następujące wnioski. (1) Refleksja Anastazego Synaity nad śmiercią jest głęboko zakorzeniona w Piśmie Świętym. To przede wszystkim z niego czerpie liczne inspiracje i metafory. (2) Mnich z Synaju nie pozostaje tylko na etapie analizowania fenomenu śmierci, lecz wskazuje konkretne środki, jak przygotować się do przejścia na drugi świat. (3) Kaznodzieja funeralny w swoim przepowiadaniu na temat śmierci odwołuje się zarówno do zagadnień teologicznych, medycznych, jak i egzystencjalnych. Mowa Anastazego Synaity wydaje się być ważnym argumentem za medycznym wykształceniem autora.

\section{Mysterium mortis according to Anastasius Sinaita}

(summary)

The article presents the thought of Anastasius Sinaita regarding death from a Christian perspective. The author tries to depict in detail the process of the dying of man. He is concerned not only about the moment of death itself, but also the accompanying circumstances. Hence, the author studies surrounding events which include speeches performed by both the person who is passing away and people surrounding him. The funeral oration is based upon the Biblical text, but also includes various themes from both human and animal life. The homily has a didactic and consolable character.

Keywords: Anastasius Sinaita; homily; last will; death; judgement; mysterium mortis

\section{Mysterium mortis w ujęciu Anastazego Synaity}

\author{
(streszczenie)
}

Artykuł prezentuje myśl Anastazego Synaity odnoszącą się do śmierci w aspekcie chrześcijańskim. Autor stara się w szczegółowy sposób opisać proces odejścia człowieka z uwzględnieniem nie tylko samego momentu śmierci, ale przedstawia cały wachlarz 
zachowań, gestów, a także wypowiedzi zarówno ze strony umierającego, jak i jemu towarzyszących. Mowę pogrzebową autor opiera na tekstach biblijnych. Wykorzystuje również motywy zaczerpnięte z życia i zachowania ludzi oraz zwierząt. Homilia ma charakter dydaktyczno-konsolacyjny.

Słowa klucze: Anastazy Synaita; homilia; testament; śmierć; sąd; mysterium mortis

\section{Bibliografia \\ Źródła}

Anastasius Sinaita, Sermo in defunctos perutilis, PG 89, 1192-1201.

\section{Opracowania}

Anastasii Sinaitae Quaestiones et responsiones, ed. M. Richard - J.A. Munitiz, Turnhout - Leuven 2006.

Anastasii Sinaitae Sermones duo in constitudinem hominis secundum imaginem Dei, necnon opuscula adversus monotheletas, ed. K.-H. Uthemann, Turnhout - Leuven 1985.

Anastasii Sinaitae Viae Dux, ed. K.-H. Uthemann, Turnhout - Leuven 2006.

Congourdeau M.-H., Médecine et théologie chez Anastase le Sinaïte, médecin, moine et didascale, w: Les Pères de l'Église face à la science médicale de leur temps, red. V. Boudon-Millot - B. Pouderon, Paris 2005.

Erotapokriseis: Early Christian Question-and-Answer Literature in Context: Proceedings of the Utrecht Colloquium, 13-14 October 2003, ed. A. Volgers - C. Zamagni, Leuven - Paris - Dudley 2004.

Hiéromoine Nicolas (Molinier), Anastase le Sinaïte, Trois Homélies, Paris 2013.

Studien zu Anastasios Sinaites. Mit einem Anhang zu Anastasios I. von Antiochien, Berlin - Boston 2017.

Uthemann K.-H., Anastaios Sinaites. Byzantinisches Christentum in den ersten Jahrzehnten unter arabischer Herrschaft, t. I-II, Berlin-Boston 2015.

Stawiszyński W., Bilbliografia patrystyczna 1901-2016, Kraków 2013. 